\title{
CRISIS IN NEOLIBERALISM OR CRISIS OF NEOLIBERALISM?
}

\author{
ALFREDO SAAD-FILHO
}

The banks are fucked, we're fucked, the country's fucked. Anonymous British cabinet minister ${ }^{1}$

$\mathrm{T}$ his rather perceptive assessment of the implications of the current crisis for the United Kingdom (and a good many other countries) is more candid and insightful than the twaddle of many mainstream journalists, economists and politicians, who proclaim the virtues of the 'free market' while blaming an unholy coalition of unhinged bankers, shifty borrowers and incompetent regulators for the disaster. ${ }^{2}$ In order to save neoliberalism from itself, the free marketeers have nationalized some of the largest financial institutions in the world, socialized financial market risks and pumped huge amounts of public money into the economy. The rhetorical gyrations justifying this frenzy have been ideological in the worst possible sense: they are deliberately misleading representations of reality, concocted to confuse the audience and stultify the opposition. In contrast, Marxian assessments of the crisis, being grounded upon the realities of accumulation and located within systemic analyses of the class relations under neoliberalism, suggest that this is not a crisis of (de)regulation but, instead, a systemic crisis in neoliberal capitalism. It is not, yet, a crisis of neoliberalism.

\section{NEOLIBERALISM AND FINANCIALIZATION}

Neoliberalism is the mode of existence of contemporary capitalism. This system of accumulation emerged gradually, since the mid-1970s, in response to the transformation of the conditions of accumulation accompanying the disarticulation of the Keynesian-social democratic consensus, the paralysis of developmentalism and the implosion of the Soviet bloc. ${ }^{3}$ In essence, neoliberalism is based on the systematic use of state power, under the ideological guise of 'non-intervention', to impose a hegemonic project of recomposition of the rule of capital at five levels: domestic resource allocation, 
international economic integration, the reproduction of the state, ideology, and the reproduction of the working class. These are summarily described below in order to locate the contradictions leading to the current crisis.

Under neoliberalism, state capacity to allocate resources intertemporally (the balance between investment and consumption), intersectorally (the composition of output and investment) and internationally (the articulation of capitalist production and finance across borders) has been systematically transferred to an increasingly globalized financial sector in which US institutions play a dominant role. ${ }^{4}$ Resource control has given the financial institutions a determining influence upon the level and composition of investment, output and employment, the structure of demand, the financing of the state, the exchange rate and the patterns of international specialization in most countries. The extended influence and resourcing of finance has supported the development of a whole array of new instruments, the rapid expansion of purely speculative activities and, inevitably, the explosive growth of rewards to high-ranking financiers. ${ }^{5}$

Financialization and the restructuring of production are underpinned by the transnationalization of circuits of accumulation, which is commonly described as 'globalization'. These developments have recomposed the previous 'national' systems of provision at a higher level of productivity at firm level, created new global production chains, reshaped the country-level integration of the world economy, and facilitated the introduction of new technologies and labour processes, while compressing real wages. ${ }^{6}$ Finally, financialization has also supported the reassertion of US imperialism. ${ }^{7}$

Financialization is not a distortion of a 'pure capitalism' or the outcome of a financial sector 'coup' against productive capital. It is, rather, a structural feature of accumulation and social reproduction under neoliberalism. In this sense, 'finance' includes not only the banks and institutional investors (pension funds, mutual funds, hedge funds, stockbrokers, insurance companies and other firms dealing primarily with interest-bearing capital), but also the financial arm of industrial capital, whose profitability increasingly depends on financial engineering. The constitutive role of finance in the capital relation under neoliberalism has allowed it to appropriate an increasing share of the profits extracted by the non-financial corporate sector. This process has played a major role in the polarization of incomes under neoliberalism. ${ }^{8}$

Even before the current crisis, the notion that finance mobilises and allocates resources efficiently, drastically reduces systemic risks and brings significant productivity gains for the economy as a whole was untenable. ${ }^{9}$ Not only did the expected acceleration of growth through financial and capital account liberalization fail to materialise in most countries but, instead, 
finance-induced crises have become more frequent. ${ }^{10}$ Conversely, the growth accelerations in the age of neoliberalism have been largely unrelated either to changes in financial sector regulations or capital account liberalization. An alternative interpretation is more plausible: regardless of these limitations, financialization plays a pivotal role in contemporary capitalism because it supports the transnationalization of production, facilitates the concentration of income and wealth and supports the political hegemony of neoliberalism through continuing threats of capital flight. The power of finance has become especially evident during the current crisis, when several governments were compelled to rescue large institutions and, in some cases, entire financial systems at huge cost to the public. Even more strikingly, these revived institutions immediately started demanding budget cuts because of the alleged 'unsustainability' of the fiscal position of states that, nominally, 'own' some of the largest banks in the land. ${ }^{11}$ Never in economic history has so much trouble and expense been rewarded with such effrontery.

\section{FINANCIALIZATION AND SOCIAL DISCIPLINE}

Neoliberal financialization has imposed specific modalities of social discipline upon key social agents. These include the state (the need to enforce restrictive welfare policies and contractionary monetary and fiscal policies under the continuing threat of fiscal, exchange rate or balance of payments crisis), industrial capital (global competition promoted by the state and facilitated by finance), and the financial sector itself (competitive international integration under a US-led regulatory umbrella). However, unquestionably the most stringent forms of discipline have been imposed upon the working class.

Hundreds of millions of workers have been forcibly incorporated into transnational circuits of accumulation during the last three decades, greatly increasing competition between individual capitals and between (and within) national working classes. The global restructuring of production, accompanied by regressive legal, regulatory and political changes, have transformed the patterns of employment in most countries and facilitated the imposition of restrictions to the wages, subsidies, benefits, entitlements systems and other non-market protections that had been introduced under various interventionist regimes. These technological, economic, legal and political shifts have drastically narrowed the scope for resistance against neoliberal capitalism.

At another level, social discipline has been imposed through the financialization of the reproduction of the working class, most remarkably by means of the housing market boom and the expansion of personal credit in the last two decades. These offered highly profitable lines of business for 
many financial institutions and became an important mechanism of social integration, especially in the US and UK. Under their chronically straitened circumstances, partly because of the disappearance (or the export) of millions of traditionally relatively well-paid skilled jobs and their replacement by less well-paid service jobs and, partly, because of the retrenchment of the welfare state, many workers were drawn into systematic borrowing while their conditions of employment deteriorated. In these circumstances, it is unsurprising that many households became either chronically indebted or increasingly reliant on asset price inflation, or both, in order to meet their reproduction needs. ${ }^{12}$ For example,

[T]here has been a 74 per cent increase in health insurance premiums for the average US family with health care coverage, which has led to 29 million American adults incurring unsecured consumer loans to make up for the gap between medical coverage and actual costs... [U]nsecured debt has also become an important contributor in granting access to university education... [M]iddleincome households are [also] using mortgage debt to supplement the lack of funding for basic education as many families now opt to pay a premium for purchasing houses within a good school catchment area... In addition to medical bills and education... a large portion of middle- and low-income households use unsecured debt as a safety net or to fund daily living expenses... [M]iddle-income households are incurring ever greater levels of debt to maintain the historically constructed notion of the American middle-class standard of living. ${ }^{13}$

Many households reacted to the neoliberal reforms by maxing out their credit cards and turning their homes and retirement pensions into virtual cash machines in order to bypass the stagnation of wages and the retrenchment of public welfare provision. ${ }^{14}$ However, pressures for timely repayment based on the threat of losing homes, cars and reputations helped to push many debtors into financial difficulties, including the need for long working hours in multiple jobs with precarious employment rights, rising stress levels and, inevitably, a declining propensity to engage in political or industrial militancy.

Unsurprisingly, financialization has supported a significant rise in the rate of exploitation foremost seen in a corresponding decline in the wage share of national income in most countries. In the US, for example, 
From 1979-2004 the [income] share of the top 5 percent of households rose from 15.3 percent to 20.9 percent while that of the poorest 20 percent fell from 5.5 percent to 4.0 percent ...

[I]ncome growth has been particularly concentrated at the very top. In 2000 and again in 2005 the richest hundredth of one percent... of families in the United States received 5 percent of total income, a level that had been not been reached previously since 1929. During the 1950s and 1960s the share received by the top 0.01 percent was between 1 percent and 1.5 percent of total income. ${ }^{15}$

Similarly, in the UK,

[The] top 0.05 per cent of the population had seen its share of national income decline ... from 1937 till the 1970 s ... but by 2000 its share was higher than it had been in 1937. And the very rich got richer faster than the merely wealthy. In the 1980s, every group in the top tenth of taxpayers increased their share of national income, but in the 1990s the increase in the share of the top tenth was all accounted for by the top 0.1 per cent ... [T] he average ratio of CEO-to-employee pay was 47 in 1999; ten years later it was $128 .{ }^{16}$

Personal credit was also a key macroeconomic policy tool. Every time the US and UK economies slowed down as, for example, in the late 1990s, after the dotcom bubble and after 9-11, their central banks lowered interest rates and encouraged remortgaging and the accumulation of unsecured debt in order to prop up demand. These policies have been referred to as 'asset price Keynesianism', ${ }^{17}$ because, to some extent, private deficits replaced the role of public sector deficits in macroeconomic stabilization. This policy was temporarily successful, and demand induced by home equity extractions added approximately 1.5 per cent per year to the rate of growth of US GDP between 2002 and 2007. Suggestively, this was just about the difference between US and Eurozone growth rates during that period. ${ }^{18}$

The significance of personal debt for social reproduction under neoliberalism does not support the right-wing view that the current crisis was caused by the profligacy of poor US and UK households. Nor does the leftpopulist claim that the indebted workers were merely victims of structural forces hold up. The analysis above does, however, imply that the crisis was the outcome of an unsustainable process of neoliberal financialization, perverse 
changes in labour market structures and regressive shifts in the provision of the means of subsistence, underpinned by limited macroeconomic policy tools and propped up by deeply ideological claims about 'competition' and 'individual choice'. The crisis also shows that it is impossible to eliminate poverty by lending to the poor: poverty has many causes, but insufficient access to credit is not one of them.

It is also impossible to stabilise complex economies over long periods through the manipulation of mass credit, above all because the material limitations in their ability to repay eventually must restrict the working class's borrowing capacity. Consequently, in extremis, their debts may have to be nationalized, inflated away or legislated out of existence. But this happens only exceptionally: under normal circumstances, excess debt leads only to individual penury and social degradation.

\section{NEOLIBERALISM'S CONTRADICTIONS}

The neoliberal system of accumulation is structurally unstable at five levels. First, the sheer weight of finance in the economy, facilitated by technological developments that reinforce financial innovations and speed financial transactions, and by regulatory liberalization, determines that accumulation under neoliberalism has often taken the form of financial (bubble-like) cycles which eventually collapse with destructive implications and requiring a state-sponsored bailout. These cycles include: the international debt crisis of the early 1980s, the US savings \& loan crisis of the 1980s, the stock market crashes of the 1980s and 1990s, the Japanese crisis of the late 1980s, the crises in several middle income countries at the end of the twentieth century, and the dotcom, financial and housing bubbles of the 2000s, culminating with the current global meltdown. It is also striking that the business model of neoliberalism's beacon enterprises is, often, based primarily on plunder and fraud, across a spectrum ranging from Enron to Bernard L. Madoff Investment Securities. Although these crises and a succession of largescale bankruptcies demonstrate the irrationalities of accumulation under neoliberalism, the illusion of prosperity was supported by the Fed's apparent ability to coordinate the clean-up operations while sustaining growth in the dynamic centre of the world economy.

Second, the latest cycle was predicated on a seemingly bottomless appetite for credit by households and the state, which provided outlets for the commodities and the fictitious capital produced by the global corporations. However, growing household consumption was sustainable only while rising house prices conjured up the equity which could be withdrawn through new loans and remortgages. ${ }^{19}$ It would eventually become impossible to service 
rising debts with stagnant household incomes - especially if interest rates had to rise in order to prick asset bubbles or keep inflation low. Rising house prices also depended on the flow of mortgage credit by the financial institutions, which was, in turn, reliant on US and UK policies to promote speculative capital inflows, buy-to-let swindles (in the UK) and predatory subprime lending (in the US) allegedly in order to 'expand home ownership'. ${ }^{20}$ These loans were sliced up and traded repeatedly among the financial institutions, generating staggering fortunes in the process. ${ }^{21}$ However, when swelling losses threatened to overwhelm the financial sector, governments swiftly collectivized risks, nationalized the imperilled institutions and plugged the sector's balance sheet with endless quantities of newly minted cash.

Third, the cycle required a continuing flow of financial resources to the US and the UK to buy shares, T-bills, mortgage-based securities and real estate. These funds were converted into tradable financial assets, allowing the intermediaries to extend credit in the domestic economy. Evidently, these transfers are ultimately unsustainable because the US and UK cannot expect to be permanently subsidized by cheap goods and cheap finance supplied by the rest of the world. Nevertheless, these resource flows temporarily supported the claim that the finance-driven restructuring of capitalism had been successful, and that the US and UK were consistently doing 'better' than the economies which embraced neoliberalism a little more reluctantly (especially Japan and the Eurozone). These performance differences in the years preceding the crisis helped to legitimize neoliberalism, and to disguise the fact that the so-called 'Great Moderation' was largely founded on unsustainable debt-led growth supported by misaligned exchange rates. ${ }^{22}$

Fourth, macroeconomic stability, predictable central bank policies, hands-off financial regulation, the Basel II framework and 'mark to market' accounting rules increased the economy's vulnerability to swings, shocks and confidence crises. They created incentives for rising leverage and for an increasing reliance by the financial institutions on short-term wholesale funding rather than retail deposits. Leveraging and the creation of liquidity through the transformation of debt into tradable papers boosted asset prices which, in turn, encouraged further leveraging, in a kind of Ponzi process. Conversely, when liquidity fell highly leveraged financial institutions had to cut their balance sheets rapidly, contributing to the severity of the crisis.

Fifth, it was expected that securitization would increase the resilience of accumulation by transferring risk to those better able to hold it. However, in reality the financial institutions lost the incentive to evaluate risk because their papers were being traded immediately, while the buyers relied on meaningless credit ratings to disguise their ignorance. ${ }^{23}$ The ensuing flood of 
securities silently destabilized global finance. ${ }^{24}$ In sum, although the trigger for the crisis was the collapse of subprime mortgages in the US, there were several weak links along the chain: the recycling of US and UK current account deficits, the rate of accumulation of personal debt, the relationship between consumption and interest rates, the fragility of the balance sheets of the large financial institutions and their structured investment vehicles, the need for low inflation and predictable changes in interest rates, and so on.

In this sense, the current crisis exposes the limitation of financialization as the driver of global accumulation. The contradictions underlying the crisis indicate that this is a systemic crisis in neoliberalism, but it is not a crisis of neoliberalism because, although the reproduction of the system of accumulation has been shaken, it is not currently threatened by a systemic alternative.

\section{NOT MOVING FORWARD}

The financial collapse delivered a stunning blow to the neoliberal consensus, as was aptly illustrated by Alan Greenspan's confession of 'shocked disbelief. ${ }^{25}$ The Economist was nothing less than apocalyptic:

$[\mathrm{E}]$ conomic liberty is under attack and capitalism ... is at bay ... but those who believe in it must fight for it ... In the short term defending capitalism means, paradoxically, state intervention. There is a justifiable sense of outrage ... that $\$ 2.5$ trillion of taxpayers' money now has to be spent on a highly rewarded industry. But the global bailout is pragmatic, not ideological ... If confidence and credit continue to dry up, a near-certain recession will become a depression, a calamity for everybody. ${ }^{26}$

For a few weeks in 2008 global capitalism seemed to bleed uncontrollably, as losses reportedly climbed towards US $\$ 40$ trillion or, alternatively, 45 per cent of the world's wealth. ${ }^{27}$ Several states nationalized key financial institutions, guaranteed deposits and financial investments, cut interest rates and implemented expansionary fiscal policies and so-called 'quantitative easing' to support finance, aggregate demand and employment. It is impossible to calculate the cost of these initiatives. They included central bank purchases of temporarily worthless financial assets, which may gain value as the global economy stabilises, 'Keynesian' initiatives to protect employment, which partly pay for themselves through additional tax revenues and reduced social security transfers, and a significant amount of borrowing to fund regular spending, which became necessary because of the crisis-driven decline in taxation. These measures were unsurprising: they reflect, on the one hand, 
the post-Great Depression consensus that aggressive expansionary policies can avert a deflationary spiral, and, on the other, the neoliberal claim that financial sector stability is paramount.

Heavy state spending and the socialization of losses and risks stemmed the haemorrhage of bank capital and postponed the collapse of some large manufacturing conglomerates, especially the old US automakers. However, they did not revive bank credit, and their huge costs have triggered severe fiscal problems especially in the US, UK, peripheral European economies and fragile Gulf states. As Joseph Stiglitz put it,

[T] he very actions that saved the economies of the world have presented a new problem for fiscal policy, as questions are being raised about governments' ability to finance their deficits. There are speculative attacks against the weakest countries, which find themselves caught between a rock and a hard place ... The financial markets that caused the crisis - which in turn caused the deficits went silent as money was being spent on the bailout; but now they are telling governments they have to cut public spending. Wages are to be cut, even if bank bonuses are to be kept. ${ }^{28}$

Despite their tactical proficiency, instantly coming up with trillions of dollars to support the banks and shore up the global economy, the neoliberal bourgeoisies and their paid economists have demonstrated a staggering lack of strategic imagination. Even the most promising recovery scenarios offers only slow growth, a decade of austerity and a wave of unemployment which may last for an entire generation. The emerging consensus is that the system of accumulation can be fixed with a little financial regulation, marginal exchange rate adjustments, a rebalancing between exports and domestic demand in Germany and East Asia, and austerity for wages and public consumption in the UK and eventually in the US. These cosmetic changes are unlikely to rebalance the global economy or make much of a contribution to managing the ongoing restructuring of accumulation. Their simplicity is symptomatic of the mainstream's superficial understanding of the crisis; they point to a slow and very bumpy recovery, with the emergence of deep financial, fiscal, exchange rate and unemployment crises in one country after another, and over a long period of time.

Most recovery plans bypass the need for an alternative mechanism of social integration, fail to recognise that the manipulation of personal debt will be insufficient to stabilise demand and employment, and ignore the fact that the contraction of credit, wages and pensions and the need for 
fiscal retrenchment will compromise long term demand growth. Although state spending has plugged the gap during the crisis, this is unsustainable without significant changes in taxation and the distribution of income, but these are not currently on the cards. ${ }^{29}$ Recovery plans also presume that contractionary fiscal policies are essential to protect state credit ratings in the short-run and avoid inflation in the long-run, and envision that, after the return of 'normal' conditions, the manipulation of interest rates should become once again the most prominent macroeconomic policy tool. That is, the neoliberal camp essentially expects the global system of accumulation to get back to its pre-crisis state (plus or minus some marginal tinkering) after a prolonged and rather costly period of instability. ${ }^{30}$

Even more alarmingly, although many proposals to address the crisis and prevent a repeat have been aired, three years after the onset of the crisis and two years after the collapse of Lehman Brothers very little of substance has actually happened. The ideas on the table or being discussed in the world's legislatures include a devaluation of the dollar to help rebalance the US economy, a coordinated set of higher inflation targets to erode public debts while preventing explosive capital movements to low inflation countries, ${ }^{31}$ the taxation of bank assets and financial transactions, a review of supervisory agency responsibilities, the prohibition of certain types of short-selling, regulatory changes requiring the financial institutions to prepare 'living wills' and/or buy insurance against possible failure, and rules to increase capital requirements countercyclically, constrain leveraging and speculation, ban proprietary trading, restrict the hedge funds and cap bonuses. Other suggestions include stricter regulation of the credit rating agencies, increased transparency in derivatives trading (for example, through the creation of centralized exchanges), and stronger consumer protection against predatory lending. ${ }^{32}$

However, no significant macroeconomic adjustments have taken place yet, and the financial institutions have been lobbying ferociously against any attempt to curb their operations. They argue that the US and UK should not deliberately maim a large industry in which they have a comparative advantage, and that taxation or regulation would lead to the mass exodus of banks, hedge funds and traders to Switzerland, Singapore or the Gulf. ${ }^{33}$ Their well-funded campaign is only part of the problem.

Macroeconomic adjustments have been hamstrung by a number of major economic challenges that remain in place. A first is the conflicting pressures on the dollar (it must fall to help correct the US current account deficit, but it tends to rise whenever there is uncertainty elsewhere, especially in the systemically important countries or the Eurozone); China's 
parallel unwillingness to let its currency appreciate is a second. Structural contradictions within the Eurozone are a further difficulty: between surplus and deficit countries; between entrenched monetary conservatism and the need to deploy expansionary policies to address the crisis in the smaller countries; and - more fundamentally - between monetary unification and continuing fiscal fragmentation.

A fourth obstacle is the extraordinarily inflexible monetary policy apparatus that has remained in place to lock in low inflation. ${ }^{34}$ Its rigidities are compounded by significant monetary policy differences between the US, Japan, the UK and the Eurozone. For example, the first two do not have legally binding inflation targets to raise, the UK cannot act in isolation, and the ECB has been built to enforce low inflation, and its governance structure makes it difficult to change course. ${ }^{35}$ Complications of a different order would arise if inflation rose too fast in certain countries, because governments would be compelled to limit their fiscal stimuli and raise interest rates, potentially stalling the recovery.

Finally, another set of difficulties concerns reaching legislative agreement about how to tax the financial sector, set capital requirements, dismantle institutions that are too big to fail (and, therefore, that have in-built incentives to behave recklessly), and unscramble players' incentives (bonuses are outrageously high in the good times, and absurd when the financial sector refuses to lend even though it is being propped up by the state). These difficulties are especially visible in the debates surrounding the financial market reform bill in the US Congress. In conclusion, the largest economic crisis since 1929 has demonstrated that transferring control of capital to finance fosters speculation and systemic instability and does not improve macroeconomic performance. Yet, the institutional imperatives of reproduction of neoliberalism make it difficult for governments to introduce a new economic policy framework.

\section{COMING OUT OF LEFT FIELD}

Although the left has been severely weakened by the neoliberal onslaught, it should seek to intervene in the current debates offering democratic policy alternatives defending jobs, salaries, pensions and welfare standards, improving the quality of investment, protecting the environment, and seeking to turn the current crisis in neoliberalism into a crisis of neoliberalism. ${ }^{36}$ These proposals can be framed, initially, along two axes.

First, no concessions should be offered on jobs, pensions or welfare. Those who benefitted disproportionately from the good times, and whose greed caused the crisis, should pay for it. Besides, offering concessions to protect 
individual employers or countries will only intensify the continuing race to the bottom under neoliberalism.

Second, the left can demand the takeover of the financial system and its transformation into a public utility. This can be justified at two levels. On the one hand, the economic argument for profits is that they encourage capitalists to invest wisely in order to multiply their capital and avoid losses. However, if the financial sector is unproductive and if its losses must be socialized, especially when they are large, there is no justification for profits in this sector. On the other hand, governments have given huge sums of money to the banks, but the banks are refusing to lend. The banks are not interested in low-risk-low-return operations, and they have to rebuild their reserves. This bottleneck is helping to perpetuate the crisis. Such a 'catch-22' is unavoidable given the institutional structure of the financial system, the imperatives of competition, and the constraints imposed by the crisis.

Nationalization without (further) compensation will cut this Gordian knot. Ideally, it should be supplemented by closing down the hedge funds and other institutions trading only between themselves and performing no productive service for the economy, pegging bankers' compensation to civil servants' salaries, imposing capital controls and centralising currency trading, abolishing the secondary markets for public securities, and creating a democratically accountable management structure for the financial sector. If the state runs the banks according to public policy goals, it will not have to accommodate short-term profitability; the banks will no longer be involved in socially destructive businesses, and society can be more certain that there will be no financial crises or bailouts in the future. At a strategic level, nationalization is important because the ownership of financial assets is at the core of the reproduction of capitalism today. Paradoxically, this is also the weakest social relation both economically and ideologically now, and a mass campaign to nationalize finance could destabilise the class relations at the core of neoliberalism.

It goes without saying that state ownership of finance does not signal the abolition of capitalism. The state had full ownership or significant control of finance in France and Iceland until a few years ago, and in Brazil and South Korea under their respective military dictatorships. Legal ownership can help, but what really matters are the objectives of government policy and which class and other interests are served by the financial institutions. As opposed to financial system-led systems, state-led co-ordination of economic activity is potentially more advantageous for the working class because the state is the only social institution that is at least potentially democratically accountable and that can influence the pattern of employment, the production and 
distribution of goods and services and the distribution of income and assets at the level of society as a whole.

In addition to the financial reforms sketched above, a democratic economic strategy can focus on the expansion of two complementary areas: the sectors producing goods and services for the workers and the poor (and where production is, often, relatively labour-intensive, as in construction and non-durable consumer goods), and the sectors that can help to relax the balance of payments constraint in deficit or vulnerable countries. They can be prioritised through the adoption of policies enforcing capital controls, maintaining exchange rates compatible with current account balance, avoiding domestic and external debt, introducing accommodating fiscal and monetary policies and rising tax ratios, and securing investment in public and environmentally sustainable goods. All these goals are compatible with a green investment strategy, which, especially in the large economies, has become imperative in order to avoid global environmental collapse.

Left mobilisation along these lines will not be welcomed by the neoliberal elite. The left should have no illusions that there is an 'antagonistic' relationship between production and finance under neoliberalism simply because financial gains are, by definition, deductions from the surplus value extracted by industrial capital. This principle is too abstract to support a political alliance between the left and the industrial - or the 'national' bourgeoisie. Industrial capital is materially committed to the reproduction of neoliberalism, and the expectation that industrial capitalists will suddenly decide to follow Keynesian, developmentalist or democratic economic policies drastically misunderstands contemporary capitalism. ${ }^{37}$

This essay has argued that neoliberalism is a material form of social reproduction and social rule encompassing the structure of accumulation, international exchanges, the state, ideology and the reproduction of the working class, and which is compatible with a wide variety of policies under a supposedly 'free-market' umbrella. This totality has been destabilized by the crisis, and the neoliberal consensus is attempting to restore the status quo ante as much as possible. This goal is grounded in the realities of social reproduction, and supported by the class alliances which structure, and benefit from, neoliberalism.

In sharp contrast with these stabilizing goals, the destabilization of neoliberalism is a project of the radical left, and the spectrum for alliances at the top is very limited. Conversely, the scope for alliances at the bottom of the world's society is, potentially, unlimited. A left strategy to transcend neoliberalism must be based on mass political movements transforming the state and the processes of socio-economic reproduction and political 
representation - that is, imposing a new system of accumulation, including a new configuration of the economy and more equal distributions of income, wealth and power.

If the global working class remains passive the crisis will be resolved through an increase in the rate of exploitation. The default position in capitalism is that the workers are not only penalised disproportionately by crises; they must also compensate the capitalists for their losses. ${ }^{38}$ This is partly because of the way in which capitalist economies absorb and process adverse shocks and, partly, because the workers are, by definition, closer to the edge of survival and have much greater difficulty turning changing circumstances to their advantage. This makes it essential to reinforce the distributional aspect of economic policy during the crisis by strengthening the links between economic and social policies in order to protect the vulnerable when they need it most (at a minimum, through the imposition of an extraordinary 'crisis tax' on the rich and on large corporations), while, at the same time, imposing progressive structural changes in the current modality of economic and social reproduction.

In sum, the alternative for the workers is to push the cost of the crisis on to the capitalists through a campaign for the takeover of the financial system and the democratization of finance, which would contribute to the destabilization of neoliberalism. Large-scale mobilizations depend on the left's ability to imagine an alternative future including the values of democracy, solidarity, satisfaction of basic needs and environmental sustainability. They can draw inspiration from the historical struggles for the limitation of the working day, for public health and education, for citizenship rights, and for the extension of democracy, in which the tireless work of millions of left activists has been essential to bring significant gains for the majority.

\section{NOTES}

1 The Guardian, 19 January 2009.

2 For example, George Osborne and Jeffrey Sachs suggest that: 'Blaming our predicament on financial markets... ignores the awkward truth that governments have enabled, if not enthusiastically promoted, recklessness, through chronic deficits and lax financial regulation'. 'A Frugal Budgetary Policy Is The Better Solution', Financial Times, 15 March 2010, p. 15; and also 'Capitalism at Bay', The Economist, 16 October 2008.

3 See Alfredo Saad-Filho, 'Introduction', in Saad-Filho, ed., Anti-Capitalism: A Marxist Introduction, London: Pluto Press, 2003; Alfredo Saad-Filho and Deborah Johnston, eds., Neoliberalism: A Critical Reader, London: Pluto Press, 2005; and Alfredo Saad-Filho and Galip Yalman, eds., Neoliberalism in Middle 
Income Countries: Policy Dilemmas, Economic Crises, Forms of Resistance, London: Routledge, 2010.

4 See, for example, Leo Panitch and Sam Gindin, 'Global Capitalism and American Empire', in Socialist Register 2004; Leo Panitch and Martijn Konings, eds., American Empire and the Political Economy of Global Finance, London: Palgrave, 2009; and Chris Rude, 'The Role of Financial Discipline in Imperial Strategy', in Socialist Register 2005.

5 For a detailed analysis of financialization in the US, see Greta Krippner, 'The Financialization of the American Economy', Socio-Economic Review, 3(2), 2005.

6 See David Kotz, 'The Financial and Economic Crisis of 2008', Review of Radical Political Economics, 41(3), 2009; and Susan Watkins, 'Shifting Sands', New Left Review, 61, 2010.

$7 \quad$ See the Socialist Register 2004 and 2005.

8 For example, and including only a subset of what has been defined as 'finance': 'In 2002, the [narrow financial] sector generated an astonishing 41 per cent of US domestic corporate profits... Average pay in the sector rose from close to the average for all industries between 1948 and 1982 to 181 per cent of it in 2007'. Martin Wolf, 'Cutting Back Financial Capitalism is America’s Big Test', 15 April 2009, available from http://www.ft.com. Also see: John Bellamy Foster and Hannah Holleman, 'The Financial Power Elite', Monthly Review, 62(1), 2010 and Kotz, 'Financial Crisis'.

9 These conclusions are undeniable. For example, '[It] is hard to argue that the new [financial] system has brought exceptional benefits to the economy generally. Economic growth and productivity in the last 25 years has been comparable to that of the 1950's and 60's, but in the earlier years the prosperity was more widely shared'. Paul Volcker, 'Remarks at the Economic Club of New York', Transcript available from http://www.econclubny.org.

10 See Carmen Reinhard and Kenneth Rogoff, This Time is Different, Princeton: Princeton University Press, 2010; and J. Stiglitz, Freefall: America, Free Markets, and the Sinking of the World Economy, London: Allen Lane, 2010.

11 For a particularly egregious example, see 'Moody's Warns US Over Credit Rating Fears', Financial Times, 4 February 2010, p. 17.

12 Needless to say, millions of working- and middle-class households have profited from financialization and asset inflation by refinancing their mortgages under more advantageous conditions or purchasing goods and services that would otherwise have remained beyond their reach. Although no generalisation across the working class is possible, there is incontrovertible evidence that large numbers of workers and members of the middle-class (however defined) have become chronically financially distressed during the last twenty years (see below).

13 Johnna Montgomerie, 'The Pursuit of (Past) Happiness? Middle-class Indebtedness and American Financialisation', New Political Economy, 14(1), 2009, pp. 16-18.

14 'In 2002 ... [the gross equity extracted from housing in the US] leaped up to equal about 8 percent of disposable personal income, and from 2004-06 they 
were in the range of 9-10 percent of disposable personal income. These huge extractions from home equity, which would not have been possible in the absence of the rapid runup in home prices, represented additional spendable funds beyond households' disposable income'. Kotz, 'Financial Crisis', p. 312.

15 Ibid., p. 310.

16 Stefan Collini, 'Blahspeak', London Review of Books, 8 April 2010, p. 31.

17 See, for example, Robert Brenner, 'Interview on the Current Crisis', 29 January 2009, available at http://www.hani.co.kr; and Christian Marazzi, The Violence of Financial Capitalism, Los Angeles: Semiotext(e), 2010, pp. 34-35.

18 Marazzi, Violence, p. 35.

19 'By the summer of 2007 housing prices had risen by 70 percent corrected for inflation since 1995. At its peak in 2007, the housing bubble created an estimated $\$ 8$ trillion in inflated new housing wealth, out of total housing wealth of $\$ 20$ trillion, or 40 percent of housing wealth'. Kotz, 'Financial Crisis', p. 311.

20 For a review of Alan Greenspan's ideologically-driven support for the property boom, see 'Greenspan's view', Le Monde diplomatique - English Edition, January 2009, available from http://mondediplo.com.

21 For a detailed study of remunerations in the financial sector, see Lucian Bebchuk, Alma Cohen and Holger Spamann, 'The Wages of Failure: Executive Compensation at Bear Stearns and Lehman 2000-2008', Working Draft, 22 November 2009, available from http://www.law.harvard.edu/faculty/ bebchuk.

22 For a starry-eyed overview of the 'Great Moderation', see Ben Bernanke, 'Remarks at the meetings of the Eastern Economic Association', Washington, 20 February 2004, available from http://www.federalreserve.gov. For a review of the US experience, see Leo Panitch and Sam Gindin, 'Finance and American Empire', in Panitch and Konings, eds., American Empire.

23 'The proposition that sophisticated modern finance was able to transfer risk to those best able to manage it has failed. The paradigm is, instead, that risk has been transferred to those least able to understand it'. Martin Wolf, 'Seeds of Its Own Destruction', 9 March 2009, available from http://blogs.ft.com.

24 For an engaging account of the transformations of finance during the last two decades, see Gillian Tett, Fool's Gold: How Unrestrained Greed Corrupted a Dream, London: Little, Brown \& Co., 2009.

25 'Testimony of Dr. Alan Greenspan to the Committee of Government Oversight and Reform', 23 October 2008, p. 2.

26 The Economist, 'Capitalism at Bay'.

27 See Alan Greenspan, 'Equities Show Us The Way to a Recovery', Financial Times, 30 March 2009, p. 13; Gillian Tett, 'Lost Through Destructive Creation', Financial Times, 9 March 2010 and 10 March 2010, available from http:// www.ft.com.

28 Joseph Stiglitz, 'The Non-Existent Hand', London Review of Books, 22 April 2010, pp. 17-18.

29 'The current economic upheaval demonstrates that access to credit is no replacement for real wage growth and adequate social protection. As such, 
political interventions to stem the current financial crisis need to address the chronic liquidity and impending solvency problems faced by the household sector... [due to] the huge stock of unsecured debt that must be serviced at the same time as asset prices are falling... Moreover, these households may no longer be able to continue funding consumption through debt if consumer credit dries up. What is more, undoubtedly households will be left footing the bill for the US government's multiple [bank] bail-out packages... Whether through increased income taxes or further reductions in government services, households are expected to face their own adversity while being relied on to jump-start the economy'. Montgomerie, 'The Pursuit of (Past) Happiness?', pp. 18-19.

30 For the IMF's current views of the road to recovery, see: Dominique StraussKahn, 'World Can Grow Faster With Right Policies', IMF Survey Magazine: In the News, 5 June 2010; and John Lipsky, 'The Road Ahead for Central Banks: Meeting New Challenges to Financial Stability', Speech at a HighLevel International Conference on Central Banks and Development of the World Economy: New Challenges and a Look Ahead, 18 June 2010, both available from http://www.imf.org

31 See Tim Leunig, 'Coordinated Inflation Could Bail Us All Out', Financial Times, 16 February 2009, p. 11.

32 See Olivier Blanchard, 'The Crisis: Basic Mechanisms, and Appropriate Policies', IMF Working Paper 09/80, April 2009, and Martin Wolf, 'Why Cautious Reform Of Finance Is The Risky Option', Financial Times, 28 April 2010, p. 13.

33 These threats of mass exit are hollow because the state, in these rival financial centres, does not have the resources to support and, if necessary, bail out the relatively aggressive institutions which might want to be based there.

34 See Alfredo Saad-Filho, 'Monetary Policy in the Neoliberal Transition', in Robert Albritton, Bob Jessop and Richard Westra, eds., Political Economy and Global Capitalism, London: Anthem Press, 2007.

35 See Thomas Palley, 'Europe's Debt Crisis and Keynes' Green Cheese Solution', 23 May 2010, available from http://blogs.ft.com.

36 For an overview of left proposals, see http://www.peri.umass.edu/safer. Propoor (democratic) economic policy alternatives to neoliberalism are reviewed in Arthur MacEwan, Neo-liberalism or Democracy?, London: Zed Books, 1999, and Alfredo Saad-Filho, 'There is Life beyond the Washington Consensus: An Introduction to Pro-Poor Macroeconomic Policies', Review of Political Economy, 19(4), 2007.

37 See the following defence of the City of London by the director-general of the Confederation of British Industry (CBI): 'The City is a vital part of the UK, not a "bloated excrescence" that unbalances the economy, the CBI directorgeneral said yesterday... Richard Lambert said the City benefited the nation as a whole... Mr Lambert said that in a free society "it is not the job of a politician - or, for that matter, of a regulator - to argue that a particular form of activity is or is not of social value"'. See: 'CBI Chief Defends City as Vital to UK', Financial Times, 4 September 2009, p. 2. 
38 'Over the past three quarters, America has seen national income rise by $\$ 200 \mathrm{bn}$ ... but profits have increased by $\$ 280$ bn while wages have fallen by $\$ 90$ bn. In Britain, where recovery has been slower, national income has grown by $£ 27$ bn since the middle of last year; higher profits have accounted for $\mathcal{E}^{24 \mathrm{bn}}$ of the rise. Wages have risen by f2bn'. See: Larry Elliott, 'So Much For The Spring of Discontent', The Guardian, 29 March 2010, p. 26. 